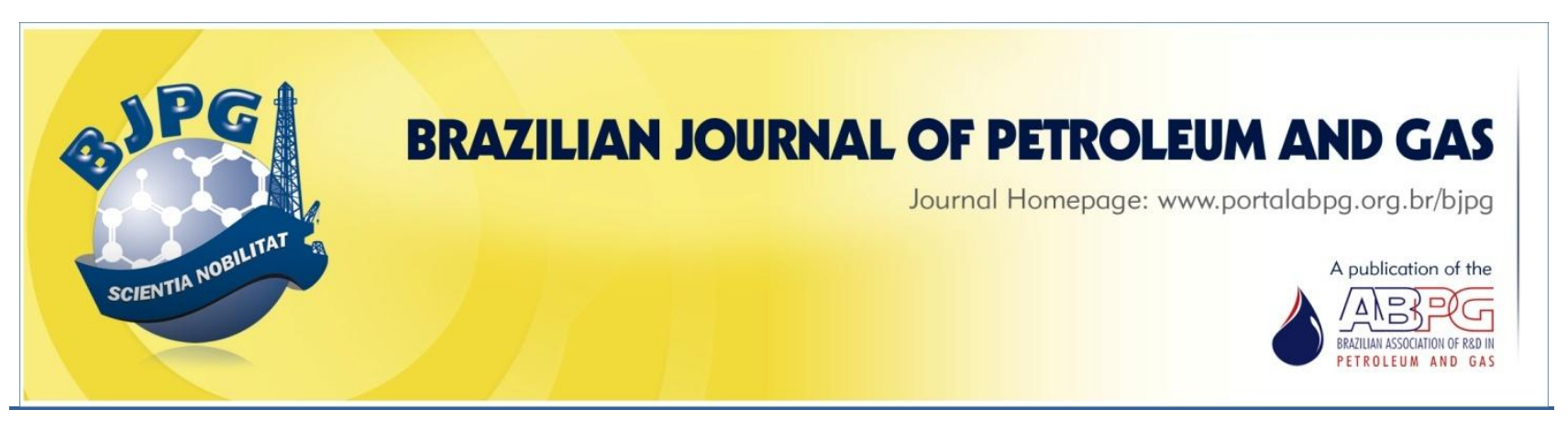

\title{
EVALUATION OF THE PURIFICATION PROCESS IN RHAMNOLIPID BIOSURFACTANT FOR APPLICATION IN MICROBIAL-ENHANCED OIL RECOVERY (MEOR)
}

\author{
${ }^{a}$ Câmara, J. M. D. A. ${ }^{1}$; ${ }^{\text {a }}$ Sousa, M. A. S. B.; ${ }^{a}$ Barros Neto, E. L.; ${ }^{\text {a }}$ Oliveira, M. C. A. \\ ${ }^{\mathrm{a}}$ Federal University of Rio Grande do Norte, Department of Chemical Engineering, Natal - RN - Brazil
}

Received: 11.04.2019 / Revised: 03.08.2019 / Accepted: 19.08.2019 / Published on line: 08.10.2019

\begin{abstract}
Biosurfactants are employed in several industrial applications which require a high purity level. However, the downstream purification processes are responsible for a large portion of the expenses incurred by biosurfactant production plants. The high costs associated with these processes turn their application on a large scale a challenge for companies. This study aimed to evaluate the influence of the purification step on the capacity of the rhamnolipid produced by a Pseudomonas aeruginosa strain to recover oil. Both purified and non-purified biosurfactants were efficient in their ability to recover oil. The best result, for the API gravity oil of 27.67 , presented a total Recovery Factor of $47.45 \pm 1.78 \%$, in which $10.2 \pm 0.85 \%$ corresponds to the MEOR. However, the results show that non-purified biosurfactant was more efficient in terms of amount of oil recovered during the MEOR stage. This demonstrates that the purification step may not be necessary, reducing the production costs of the rhamnolipid.
\end{abstract}

\section{KEYWORDS}

Pseudomonas aeruginosa; biosurfactant; rhamnolipid; microbial-enhanced oil recovery; purification process

\footnotetext{
${ }^{1}$ To whom all correspondence should be addressed.

Address: Universidade Federal do Rio Grande do Norte, Programa de Pós-Graduação em Engenharia Química, Lagoa Nova, Natal - RN - Brasil.

ZIP Code: 59078-970 | Phone number: +55 84 99664-7208 | e-mail: jessicacamara.eq@gmail.com doi:10.5419/bjpg2019-0016
} 


\section{INTRODUCTION}

Typically, 35 to $55 \%$ of the oil remains trapped in the reservoir after primary and secondary recoveries (Fan et al., 2018; Safdel et al., 2017). Nevertheless, the demand for energy and the depletion of conventional oil reserves continue to increase. These factors are the main motivation for scientists to explore more efficient methods of increasing oil recovery when water injection is no longer an economically viable alternative (Geetha; Banat \& Joshi, 2018; Malik et al., 2016; Zendehboudi et al., 2013).

The oil trapped must be extracted by different enhanced oil recovery techniques, such as miscible gas injection, polymer injection, and thermal methods (Zahid \& Sajid, 2007). The use of chemical surfactants is the technique which is most used by the oil industry for enhanced oil recovery over the decades (Curbelo et al., 2008; Mulligan, 2005). Surfactants have the capacity to reduce oil-water interfacial tension, requiring better capillary pressure to mobilize the oil (Al-Amodi et al., 2016; Al-Wahaibi et al., 2014; Babadagli, 2005; Fernandes et al., 2016). For this effect to be efficient, high concentrations of surfactant are required, leading to high costs (Youssef et al., 2013).

Thus, the development of low-cost effective techniques that lead to improvements on enhanced oil recovery is one of the most attractive topics of recent research (Safdel et al., 2017). In this context, the Microbial Enhanced Oil Recovery (MEOR) emerges as a potential low-cost technique (Desai \& Banat, 1997; Khajepour et al., 2014).

MEOR is considered a tertiary recovery technique which can extract the residual oil by using microorganisms or their products (e.g. biosurfactants) (Alvarez, Jurelevicius, and Marques, 2015; El-Sheshtawy et al., 2015; Joshi et al., 2008). Rhamnolipids are among the most wellknown biosurfactants. In addition, several studies suggest promising products for use in enhanced oil recovery (Amani et al., 2010).

Rhamnolipids are produced mainly by Pseudomonas aeruginosa (Desai \& Banat, 1997; Hassan et al., 2016). This biosurfactant has the potential to emulsify the crude oil, reducing the oilwater interfacial tension and, therefore, mobilizing the trapped oil (Mcinerney; Nagle \& Knapp, 2005;
Zhao et al., 2016). However, its large-scale production is still a challenge, mainly due to downstream processing and purification issues, which can represent from 60 to $70 \%$ of the production costs (Geetha; Banat \& Joshi, 2018; Joshi et al., 2008; Makkar; Cameotra, \& Banat, 2011; Al-Bahry et al., 2013).

Therefore, in this article, a rhamnolipid was produced from a Pseudomonas aeruginosa strain isolated from an artificially contaminated soil. The biosurfactant was studied following two approaches, after a purification process and in its crude form (fermented, free of cells), to evaluate the influence of the purification step related to the features and abilities of the product. Both of them were evaluated for their ability to reduce the water surface tension and to emulsify crude oil and, consequently, their ability to increase the rates of oil produced after conventional recovery.

\section{MATERIALS AND METHODS}

\subsection{Bacterial strain}

We used a stain of Pseudomonas aeruginosa, sourced as reported by Câmara et al. (2019). The strain was isolated from a soil artificially contaminated, and stored at $-20^{\circ} \mathrm{C}$ in skim milk.

\subsection{Rhamnolipid}

The biosurfactant was produced in $125 \mathrm{~mL}$ erlenmeyers containing $50 \mathrm{~mL}$ of the medium, which were incubated at $30^{\circ} \mathrm{C}$, under a stirring of $200 \mathrm{rpm}$, for 10 days on a rotary shaker. The medium used was optimized in prior experiments $\left(125 \mathrm{~g} / \mathrm{L}\right.$ of glycerol, $3.86 \mathrm{~g} / \mathrm{L} \mathrm{NaNO}_{3}, 0.5 \mathrm{~g} / \mathrm{L}$ $\mathrm{MgSO}_{4} .7 \mathrm{H}_{2} \mathrm{O}, 1.0 \mathrm{~g} / \mathrm{L} \mathrm{K} \mathrm{HPO}_{4}$, and $0.5 \mathrm{~g} / \mathrm{L} \mathrm{KH}_{2} \mathrm{PO}_{4}$ ). As inoculum, a nutrient solution of peptone $(2 \mathrm{~g} / \mathrm{L})$ was used, which remained in shaker at $200 \mathrm{rpm}$ and $30{ }^{\circ} \mathrm{C}$ for $24 \mathrm{~h}$ (Miguez et al., 2012). After inoculation, the medium had an initial concentration of $15 \mathrm{mg} / \mathrm{L}$ of cells.

After 10 days of fermentation, the medium was centrifuged at $3500 \mathrm{rpm}$ for 20 minutes. Thereafter, the cell-free medium was separated into two samples, one remained in its raw state and another went through the purification process.

To purify the biosurfactant, the cell-free 
supernatant was subjected to an acid precipitation. The medium was adjusted to a $2.0 \mathrm{pH}$ with a 6 $\mathrm{mol} / \mathrm{L}$ solution of hydrochloric acid $(\mathrm{HCl})$ and spent approximately 12 hours (overnight) at a temperature of $4{ }^{\circ} \mathrm{C}$. Subsequently, the biosurfactant precipitate was separated by centrifugation at $3500 \mathrm{rpm}$ for $20 \mathrm{~min}$ and washed with acidified water $(2.0 \mathrm{pH})$ twice, to remove remaining impurities, such as bacterial cells. Finally, the precipitate was dissolved in distilled water and the $\mathrm{pH}$ was adjusted to 7.0 with a solution of sodium hydroxide $(\mathrm{NaOH}) 1 \mathrm{~mol} / \mathrm{L}$ (El-Sheshtawy et al., 2015; Pereira et al., 2013).

\subsection{Biosurfactant characterization}

Crude and purified biosurfactant were diluted in distilled water to generate solutions ranging from $25 \mathrm{mg} / \mathrm{L}$ to $260 \mathrm{mg} / \mathrm{L}$. They were used to determine the surface tension and emulsion rate of the crude oil.

The surface tension (ST, $\mathrm{mN} / \mathrm{m}$ ) was determined by a Phoenix ${ }^{\circledR}$ tensiometer at $25^{\circ} \mathrm{C}$ by the pendent drop method. The results were obtained through an image processing system coupled to a computer in which the bending curvature profile of each drop contained at the tip of the needle was analyzed to determine the ST (Song \& Springer, 1996). A tendrop measurement was used to calculate the arithmetic mean and standard error. With these results, a curve relating surface tensions and their respective concentrations was projected to determine the critical micelle concentration (CMC), i.e., the concentration at which the formation of micelles starts (El-Sheshtawy et al., 2015).

The rhamnolipid solution emulsification activity was determined by the emulsion index $\left(E_{24}\right)$. In general, $2 \mathrm{~mL}$ of the biosurfactant were placed in a test tube, together with $2 \mathrm{~mL}$ of petroleum. After vigorously stirring the solution for $2 \mathrm{~min}$, the test tube was held for $24 \mathrm{~h}$ at room temperature and, then, the emulsion heights were measured. The emulsion index was calculated from the ratio of the emulsion height to the total height (Cooper \& Goldenberg, 1987; Yeh; Wei, \& Chang, 2005).

\subsection{Evaluation of superficial concentration} excess of the biosurfactant at the interface

In aqueous solutions, surfactants generally have two trends. The first one is its adsorption at the interface, and the second one is its aggregation and the formation of micelles. The first option corresponds to the surfactants equilibrium activity at the interface (Li et al., 2007; Santos et al., 2009).

The adsorption extent on a liquid surface was determined by surface tension data and it is based on the Gibbs Adsorption Equation. Thus, it was possible to estimate the adsorption per unit area of surface excess concentration, $\Gamma$ (Santos et al., 2009).

According to Gibbs, the surface excess concentration is given by the isotherm slope before the $\mathrm{CMC}$ value. This can be seen in Equation (1) for non-ionic surfactants (Castro Dantas et al., 2002; Eastoe \& Dalton, 2000; Gurkov et al., 2005; Jönsson; Kronberg, \& Lindman, 2003).

$\frac{1}{\Gamma}=-R T \frac{d(\ln C)}{d \gamma}$

Where:

$\gamma=$ the surface tension at equilibrium $(\mathrm{mN} / \mathrm{m})$ for a surfactant solution concentration $\mathrm{C}(\mathrm{mol} / \mathrm{L}) \mathrm{R}=$ the universal gas constant $\left(8.314 \times 10^{-3} \mathrm{~kJ} / \mathrm{mol} \bullet \mathrm{K}\right)$

$\mathrm{T}=$ the temperature $(\mathrm{K})$, and

$d(\ln C) / d \gamma=$ the curve slope before the $\mathrm{CMC}$ value.

From the $\Gamma$ value, it is possible to estimate the surface area occupied by each surfactant molecule, in $\mathrm{m}^{2}$, as denominated by $\mathrm{A}$ in Equation (2).

$A=\frac{10^{-20}}{N_{A} \Gamma}$

Where:

$\mathrm{N}_{\mathrm{A}}=$ Avogadro's number .

\subsection{Recovery trials}

\subsubsection{Preparation of the synthetic sandstone plug}

The recovery trials used synthetic sandstone plugs, which were composed of $0.4 \mathrm{~g} / \mathrm{g}$ clay from Lagoa dos Velhos (RN, Brazil) and $0.6 \mathrm{~g} / \mathrm{g}$ of sand from Redinha beach (Natal/RN, Brazil). The mixture was hydrated with water and, then, compacted at 
19.61 MPa and sintered at $850{ }^{\circ} \mathrm{C}$ during $3 \mathrm{~h}$ (Costa et al., 2017).

A porosity value of $20.49 \pm 0.69 \%$ was obtained for the produced plug. This property was determined by the capillary rise method, in which the pore volume is obtained from the mass difference between the dry plug and the plug totally saturated with water. Thus, the porosity was obtained by the ratio between pore volume, corresponding to the volume of water absorbed, and total volume, which is calculated by the measurements made with a caliper. The result obtained is consistent with the values of natural sandstones used in enhanced recovery studies (Costa et al., 2017).

The permeability of the developed plugs presented an average value of $36.24 \pm 1.88 \mathrm{mD}$. This property was determined through an experiment using the fluid injection system (Costa et al., 2017), shown in Figure 1. Thus, the pressure and data obtained, along with the water viscosity, the length and the sandstone straight section area were applied in Darcy's Law for linear flow.

\subsubsection{Brine}

A saline solution, composed of $2 \% \mathrm{~m} / \mathrm{v}$ of potassium chloride $(\mathrm{KCl})$ and $0.2 \% \mathrm{~m} / \mathrm{v}$ of calcium chloride $\left(\mathrm{CaCl}_{2}\right)$, was used in the injection of fluids to simulate conventional recovery, as well as salinity of a reservoir (Câmara et al., 2019). These were chosen because they are the most typical salts present in oil reservoirs at the Fazenda Belém Field (CE, Brazil).

\subsubsection{Petroleum}

The oil provided for this study by the Fazenda Belém Field (CE, Brazil) is classified as a heavy oil (API gravity of 14). Due to its high viscosity, it was not possible to use the crude oil directly in the fluid injection system. In addition, the oil did not fit into the indication range of surfactant injection as enhanced recovery method. Therefore, three solutions of 300,400 and $500 \mathrm{~g} / \mathrm{L}$ of oil were prepared, diluted in S10 diesel, presenting API gravity values of $30.34,27.67$ and 21.90, respectively. The first two oil solutions can be classified as medium, while the third is in the transition between medium and heavy. Thus, the oil samples studied were consistent with the viscosity of the petroleum present in the studied reservoirs.

\subsubsection{Microbial Enhanced Oil Recovery (MEOR)}

Recovery assays were performed on the same fluid injection system shown in Figure 1, according to the method described by Câmara et al. (2019). Briefly, the sandstone plug was first saturated with the saline solution at a flow rate of $1 \mathrm{~mL} / \mathrm{min}$ for $100 \mathrm{~min}$ followed by the petroleum solution. This second step also had a duration of $100 \mathrm{~min}$ and occurred at a flow rate of $1 \mathrm{~mL} / \mathrm{min}$.

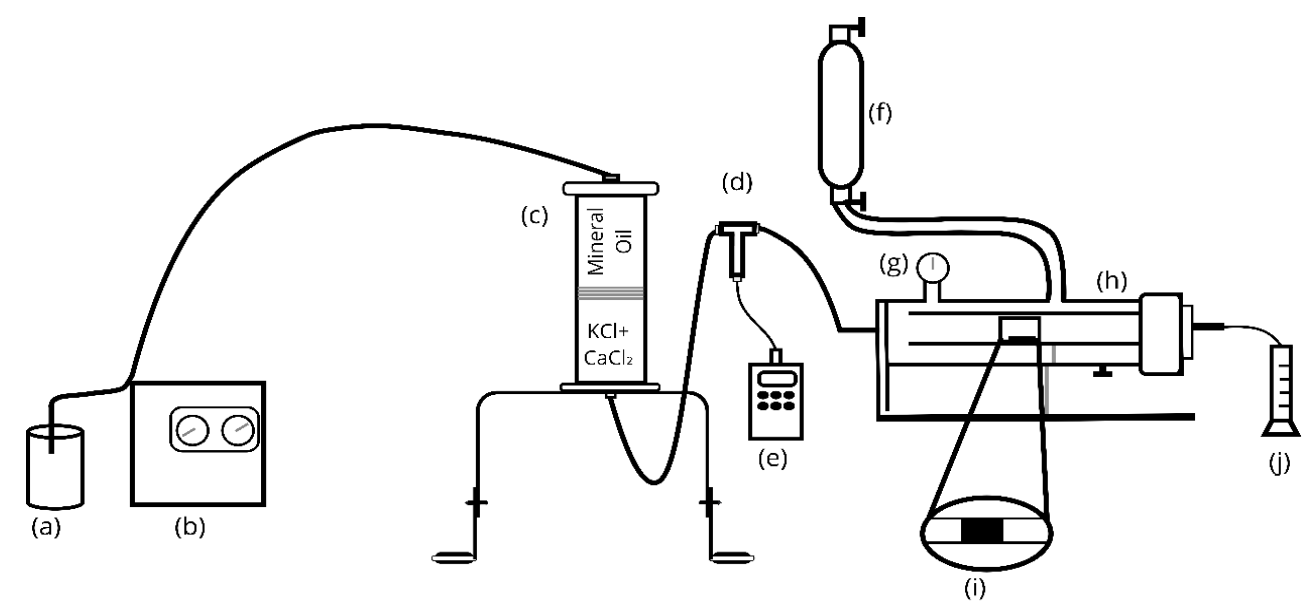

Figure 1. Fluid injection system: (a) mineral oil reservoir; (b) positive displacement pump; (c) injection cell; (d) and (e) pressure taps and pressure gauge; (f) source of compressed air; (g) holder manometer; (h) holder; (i) plug; (j) test tube. Source: Câmara et al. (2019) and Costa et al. (2017) 


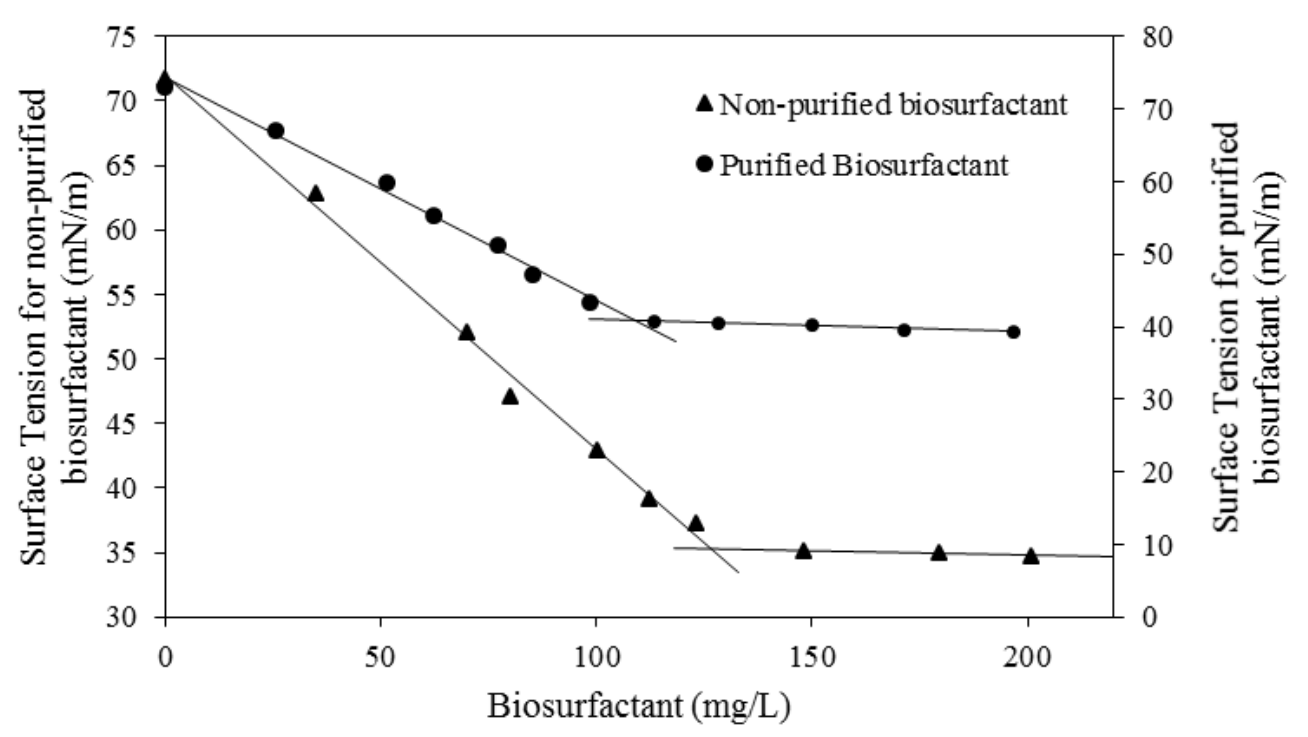

Figure 2. Surface tension versus concentration of the purified and non-purified rhamnolipid.

Subsequently, the saline solution was again injected at a flow rate of $0.7 \mathrm{~mL} / \mathrm{min}$ for $85 \mathrm{~min}$. This step aimed to simulate conventional recovery and 20 samples were collected, which were then analyzed to determine the amount of oil recovered. Finally, the rhamnolipid solution with a concentration of $50 \%$ above the $\mathrm{CMC}$ was injected following the previous step to simulate the MEOR. The ideal concentration of biosurfactant was defined in a previous work, which indicated that high concentrations of surfactant favor the formation of emulsions. It difficults the oil/water separation in treatment units (Curbelo; Garnica, \& Neto, 2013). The experiments were performed in triplicate.

\subsubsection{Analysis of the petroleum samples}

The separation of the organic phase from the petroleum samples obtained in the conventional and enhanced recovery experiments was performed by the addition of a fixed volume of kerosene to each sample, followed by shaking and centrifugation. Subsequently, the organic phase was diluted, when necessary, and readings were taken on the UV-Visible spectrophotometer, Model 50 Conc, at $400.1 \mathrm{~nm}$, to allow the calculation of the oil concentration from the previously elaborated calibration curve (Câmara et al., 2019).

\section{RESULTS AND DISCUSSION}

\subsection{Surface activities of the biosurfactants produced}

The surface tensions of both biosurfactants produced, cell-free extract and purified extract, were measured as a concentration function, as shown in Figure 2. As can it be seen in the figures, the surface tension of pure water decreases rapidly as the concentration of the biosurfactant increases. In this study, the rhamnolipid present in the cellfree extract was able to reduce the surface tension from 72 to $35.26 \mathrm{mN} / \mathrm{m}$ and the CMC was found at $127 \mathrm{mg} / \mathrm{L}$ (as shown in the left $\mathrm{y}$-axis in Figure 2).

The rhamnolipid biosurfactant that underwent a purification process was able to reduce the surface tension from 72 to $40.79 \mathrm{mN} / \mathrm{m}$ at a CMC of 110 $\mathrm{mg} / \mathrm{L}$ (as shown in the right $\mathrm{y}$-axis in Figure 2 ). The highest value of $\mathrm{CMC}$ obtained for the cell free extract, i.e. that were not purified, can be attributed to the presence of impurities in the solution that can delay the formation of micelles, requiring a higher concentration of biosurfactant molecules in the solution (Pornsunthorntawee et al., 2008).

The lowest reduction of the surface tension to the purified biosurfactant can be attributed to the purification process itself. Since it is necessary to 
Table 1. Parameters of adsorption at the water-air interface.

\begin{tabular}{ccc}
\hline Biosurfactant & $\Gamma\left(\mathrm{mol} / \mathrm{m}^{2}\right)$ & $\mathrm{A}\left(\times 10^{-20} \mathrm{~m}^{2} /\right.$ molecule $)$ \\
\hline Non-purified & $7.51 \times 10^{-6}$ & 22.10 \\
Purified & $6.90 \times 10^{-6}$ & 24.05 \\
\hline
\end{tabular}

acidify the solution to $\mathrm{pH}$ of 2.0 with hydrochloric acid $(\mathrm{HCl})$, the rhamnolipid molecules can undergo protonation of the carboxylate ions (Sousa et al., 2014), modifying their structure and affecting the formation of micelles., since the micelle configuration depends on the hydrocarbon chain structure (Castro Dantas et al., 2002).

Although the free extract of cells had better properties regarding the greater reduction of surface tension, both presented values that were consistent with the literature. In general, the biosurfactant produced by Pseudomonas aeruginosa is able to reduce the surface tension of pure water from 72 to $30 \mathrm{mN} / \mathrm{m}$ with CMCs in the range of $5-200 \mathrm{mg} / \mathrm{L}$, depending on the components present (Healy; Devine, \& Murphy, 1997; Pornsunthorntawee et al., 2008).

\subsection{Adsorption at the water-air interface}

From the data obtained through the surface tension as a function of the rhamnolipid concentration, it was possible to determine the adsorption parameters at the water-air interface. These values were determined based on the adsorption isotherms using the Gibbs Equation for non-ionic surfactants. The values are summarized in Table 1.

These results indicate that, due to the greater area occupied by the purified surfactant, a smaller amount of surfactant molecules is required to saturate the interface $(\Gamma)$ (Santos et al., 2009). Additionally, the structural differences in the hydrocarbon chains are responsible for the configuration of the micelles (Castro Dantas et al., 2002). These results justify the large surface area per molecule for the purified bioproduct. Besides, it is in accordance with the fact that the rhamnolipid molecules undergo protonation of the carboxylate ions during the purification process.

\subsection{Emulsification rate}

The ability of both rhamnolipids to stabilize an emulsion was evaluated for a concentration range from $50 \mathrm{mg} / \mathrm{L}$ to $260 \mathrm{mg} / \mathrm{L}$. This methodology was adopted because this property is a function of the concentration of the biosurfactant in the medium (Cooper \& Goldenberg, 1987; Deepika et al., 2016).

Similar to what occurred with the reduction of surface tension, the ability of the non-purified rhamnolipid to emulsify the oil was greater than that of the purified biosurfactant. The maximum emulsification rate $\left(E_{24}\right)$ was $69 \%$ and $65 \%$, respectively. However, both results are consistent with other studies, which obtained an emulsion rate of 68\% (Amani et al., 2010) and 85\% (Amani, 2015).

Therefore, as the emulsification depends on the formation of micelles, the acidification of the solution to the purification of the biosurfactant can also cause alterations in this process due to the protonation of the carboxylate ions (Sousa et al., 2014). This modification in the structure allowed the purified rhamnolipid to obtain lower emulsification rates. However, the results obtained showed that both extracts are suitable candidates for application in MEOR.

\subsection{Microbial enhanced oil recovery (MEOR)}

The results of the six MEOR tests developed in this work, for the three types of oil and two types of biosurfactant, were represented in a relation between the Recovery Factor (\%) and the pore volume injected, in Figures 3 and 4 . The first parameter is the relation between the recovered oil volume and the volume of oil present in the rock. The second parameter is the ratio between the injected fluid volume and the pore volume of the rock, which is a dimensionless measure. By 


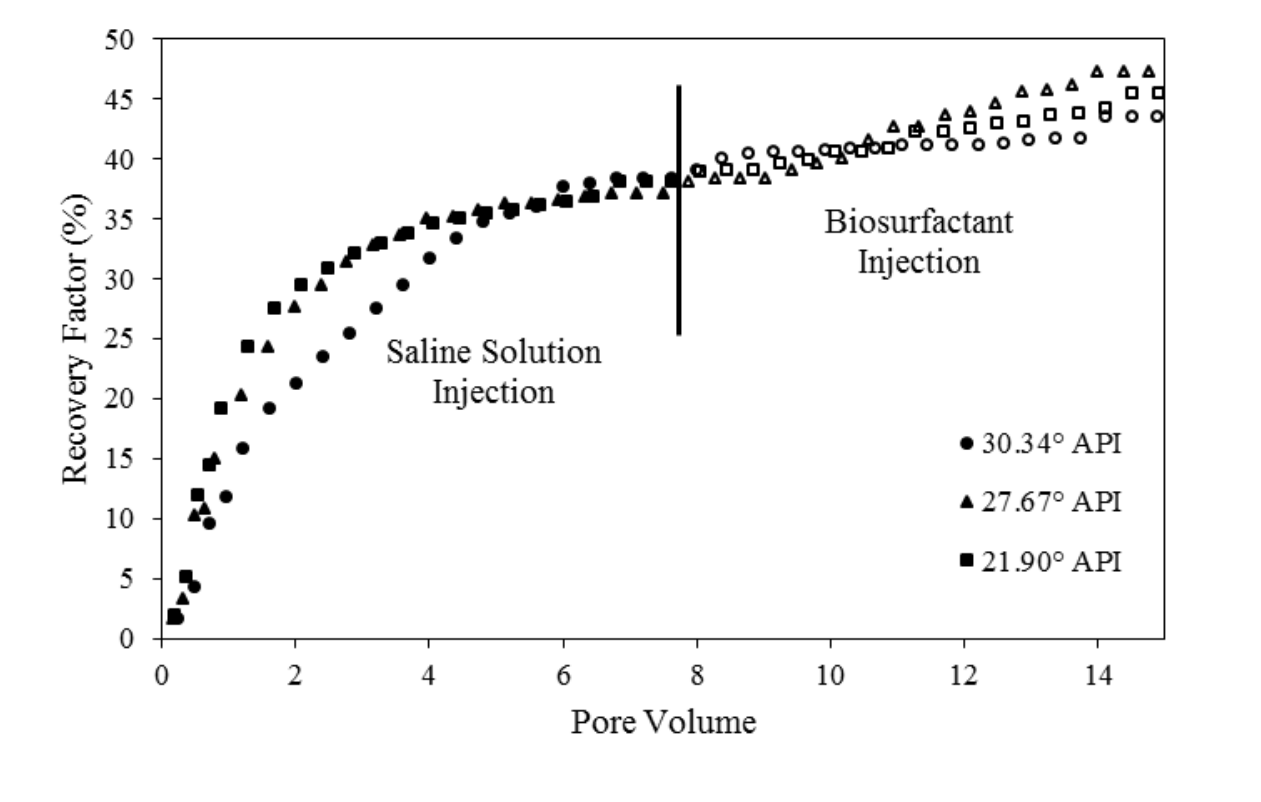

Figure 3. Recovery Factor as a function of pore volume injected to non-purified biosurfactant solution (cell-free extract).

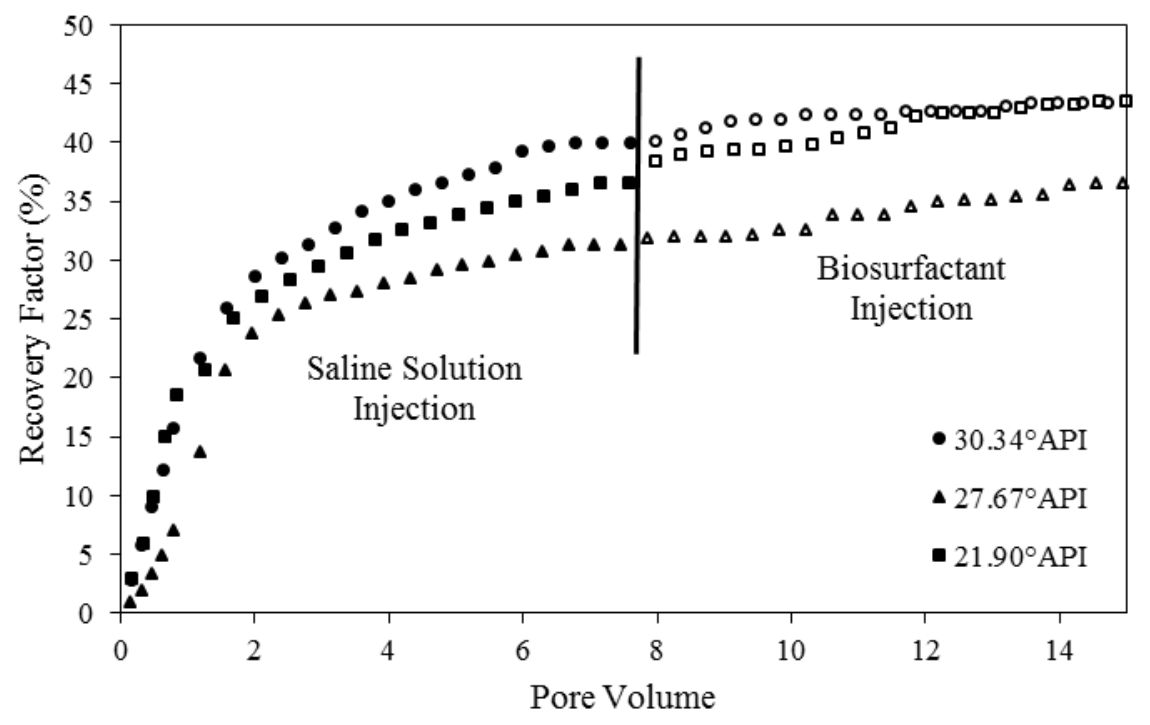

Figure 4. Recovery Factor as a function of pore volume injected into purified biosurfactant solution.

adopting these parameters, it is possible to compare results obtained in reservoirs of different dimensions.

For the six studied situations, a stabilization of the oil production occurred after the injection of approximately six pore volumes of saline solution. It indicates that there is no longer oil production in the conventional recovery process, requiring the adoption of a tertiary recovery method. For all the considered situations, the recovery factor after the saline injection did not exceed $40 \%$, as shown in
Table 2. This result is in accordance with what happens in oil fields, where 50 to $60 \%$ of the oil remains trapped in the reservoir after secondary recovery (Al-Wahaibi et al., 2016; Geetha, Banat \& Joshi, 2018; Rudyk et al., 2017).

In all the cases studied, the largest oil removal during tertiary recovery occurred after the injection of four pore volumes. This increase in the oil production was related to the reduction of interfacial tension between water and oil due to the increase in biosurfactant molecules present in 
Table 2. Summary of Recovery Factors for MEOR trials.

\begin{tabular}{ccccc}
\hline $\begin{array}{c}\text { Rhamnolipid } \\
\text { Solution }\end{array}$ & Petroleum & $\begin{array}{c}\text { Conventional } \\
\text { Recovery Factor }\end{array}$ & $\begin{array}{c}\text { Enhanced Recovery } \\
\text { Factor }\end{array}$ & $\begin{array}{c}\text { Total Recovery } \\
\text { Factor }\end{array}$ \\
\hline \multirow{2}{*}{ Non-purified } & $21.90^{\circ} \mathrm{API}$ & $38.08 \pm 1.12 \%$ & $7.67 \pm 0.77 \%$ & $45.75 \pm 1.19 \%$ \\
& $27.67^{\circ} \mathrm{API}$ & $37.20 \pm 1.17 \%$ & $10.24 \pm 0.85 \%$ & $47.45 \pm 1.78 \%$ \\
& $30.34^{\circ} \mathrm{API}$ & $38.42 \pm 0.70 \%$ & $5.13 \pm 0.59 \%$ & $43.55 \pm 0.11 \%$ \\
\hline \multirow{2}{*}{ Purified } & $21.90^{\circ} \mathrm{API}$ & $36.62 \pm 0.95 \%$ & $6.89 \pm 0.33 \%$ & $43.51 \pm 1.28 \%$ \\
& $27.67^{\circ} \mathrm{API}$ & $31.39 \pm 1.07 \%$ & $5.17 \pm 0.68 \%$ & $36.56 \pm 1.01 \%$ \\
& $30.34^{\circ} \mathrm{API}$ & $39.95 \pm 1.18 \%$ & $3.40 \pm 0.28 \%$ & $43.35 \pm 1.18 \%$ \\
\hline
\end{tabular}

the system. These molecules are distributed between the interface and allows the trapped oil to be extracted (Khajepour et al., 2014; Kumar \& Mandal, 2017).

In general, the results presented values consistent with those obtained in previous studies. In tests performed with the rhamnolipid produced by $P$. aeruginosa SP4, a total recovery factor of $57.01 \pm 0.58 \%$ was obtained (Pornsunthorntawee et al., 2008). For the biosurfactant produced by Enterobacter cloacae strain, it was possible to obtain a total recovery factor of $50.5 \%$, of which a value of $4.4 \%$ was obtained after the injection of the microbial fermentation product (Khajepour et al., 2014). The highest total recovery factor of previous studies can be attributed to the experimental methodology applied, since the study carried out with $P$. aeruginosa SP4 used a compacted sand column system and the one performed with the Enterobacter cloacae used a glass microstructure system. By using synthetic sandstone plugs, this study approached the conditions in studied oil reservoirs (Costa et al., 2017), both referring to the rock (Bryant et al., 1994) and to permeability (Safdel et al., 2017).

In view of the results, one can observe that the oil with the highest API grade obtained a greater factor of conventional recovery. This fact is justified by the distinct mobility between water and more viscous oils (lower API gravity), which favors the formation of preferential paths (Thomas, 2001). In addition, oil solutions with higher API gravity favor the formation of asphaltene aggregates (Mozaffari et al., 2015). They are adsorbed at the water-oil interface causing different interface behaviors and making oil recovery difficult (Liu et al., 2017; Soleymanzadeh et al., 2018).
As an exception, the recovery factor of the conventional oil of API gravity 27.67 was the smallest among all oil samples used during the experiment with the purified biosurfactant, reaching a value of approximately $31.39 \%$. It is related to the permeability of the three used sandstones, which was an average value of $33 \mathrm{mD}$, considerably lower than the general average of 36 $\mathrm{mD}$. This parameter exerts a great influence on the amount of oil extracted and has to be considered during the evaluation of the results. The reason is because the permeability is a crucial variable to evaluate the performance of the oil recovery, since it measures the ability of the fluid to flow through a porous system (Anderson, 1986; Craig Jr., 1993; Khajepour et al., 2014). Besides that, the pore morphology determines the limit of the capillary pressure required for the oil mobilization (Armstrong, Wildenschild, and Bay, 2015).

Nevertheless, the non-purified rhamnolipid obtained better results for all the studied oils, i.e., a higher recovery factor of the enhanced stage. The largest difference was obtained for the oil with API gravity of 27.67 which, using the non-purified biosurfactant, obtained an enhanced recovery rate approximately 98\% higher than the purified biosurfactant. For the heavier oil this difference was $12 \%$ and for the lighter oil it was $50 \%$. Although both were used at a concentration of $50 \%$ above $\mathrm{CMC}$, this result can be justified by the presence of additional compounds in the nonpurified extract, such as other metabolites produced by the bacteria and the non-metabolized substrate. These substances can act synergistically with the biosurfactant promoting greater mobilization of petroleum (Fernandes et al., 2016). 
Thus, the results achieved in this study indicate that downstream purification processes may not be necessary. These processes are responsible for a significant portion of the of large-scale production costs of biosurfactant. Although, despite the differences presented, both biosurfactants studied proved to be effective in increasing the recovered oil factor after conventional recovery. They showed significant results when compared to other biosurfactants and synthetic surfactants. This can be attributed to the presence of two carbon chains in their chemical structure, which causes a greater hydrophobic nature of the compound and results in good oil solubilization and recovery (Pornsunthorntawee et al., 2008).

\section{CONCLUSIONS}

In this study, the biosurfactant produced by a Pseudomonas aeruginosa strain after undergoing a downstream purification process was able to reduce the water surface tension to $40.79 \mathrm{mN} / \mathrm{m}$ and to emulsify the oil at a rate of $65 \%$. These characteristics demonstrate the ability to use purified rhamnolipid in enhanced oil recovery processes.

However, the cell free extract (non-purified biosurfactant) also presented evidences to be a good candidate for application in MEOR. It was able to reduce the water surface tension to 35.26 $\mathrm{mN} / \mathrm{m}$ and to emulsify the crude oil at a rate of $69 \%$.

In view of this, both purified and non-purified biosurfactants were evaluated for their ability to recover oil. In all the developed trials, for the three types of oil studied, the non-purified biosurfactant increased the recovered oil factor more efficiently after the conventional recovery. The best result obtained was for the oil with API gravity of 27.97, reaching a Total Recovery Factor of $47.45 \pm 1.78 \%$, of which $10.24 \pm 0.85 \%$ corresponds to the improved recovery by microorganism.

Therefore, this work demonstrates that rhamnolipids can be used efficiently in MEOR applications. In addition, it emphasizes that the application of high investment purification processes may not be required, since the presence of additional compounds into the extract can act synergistically promoting a greater oil removal.

\section{ACKNOWLEDGMENTS}

The authors thank Coordenação de Aperfeiçoamento de Pessoal de Nível Superior (CAPES) for the financial support.

\section{NOMENCLATURE}

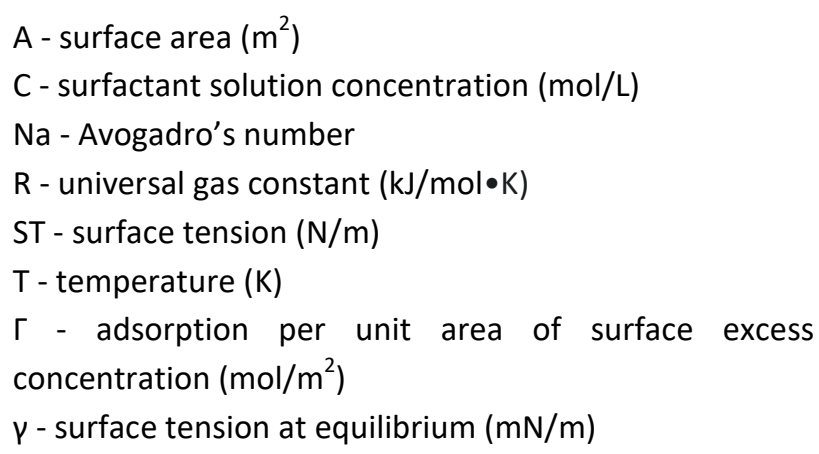

\section{REFERENCES}

Al-Amodi, A. O.; Al-Amodi, A. O.; Al-Mubaiyedh, U. A. Sultan, A. S.; Kamal, M. S.; Hussein, I. A. Novel fluorinated surfactants for enhanced oil recovery in carbonate reservoirs. Canadian Journal of Chemical Engineering, v. 94(3), p. 454-460, 2016. https://doi.org/10.1002/cjce.22406

Al-Bahry, S. N.; Al-Wahaibi, Y. M.; Elshafie, A. E.; Al-Bemani, A. S.; Joshi, S. J.; Al-Makhmari, H. S.; AlSulaimani, H. S. Biosurfactant production by Bacillus subtilis B20 using date molasses and its possible application in enhanced oil recovery. International Biodeterioration \& Biodegradation, v. 81, p. 141-146, 2013.

https://doi.org/10.1016/j.ibiod.2012.01.006

Al-Wahaibi, Y.; Joshi, S.; Al-Bahry, S.; Elshafie, A.; Al-Bemani, A.; Shibulal, B. Biosurfactant production by Bacillus subtilis $B 30$ and its application in enhancing oil recovery. Colloids and Surfaces B: Biointerfaces, v. 114, p. 324-333, 2014. https://doi.org/10.1016/i.colsurfb.2013.09.022

Al-Wahaibi, Y.; Al-Hadrami, H.; Al-Bahry, S.; Elshafie, A.; Al-Bemani, A.; Joshi, S. Injection of biosurfactant and chemical surfactant following hot water injection to enhance heavy oil recovery. Petroleum Science, v. 13(1), p. 100-109, 2016. https://doi.org/10.1007/s12182-015-0067-0 
Alvarez, V.; Jurelevicius, D.; Marques, J. Bacillus amyloliquefaciens TSBSO 3.8, a biosurfactantproducing strain with biotechnological potential for microbial enhanced oil recovery. Colloids and Surfaces B:, v. 136, p. 14-21, 2015.

https://doi.org/10.1016/j.colsurfb.2015.08.046

Amani, H.; Sarrafzadeh, M. H.; Haghighi, M.; Mahrnia, M. R. Comparative study of biosurfactant producing bacteria in MEOR applications. Journal of Petroleum Science and Engineering, v. 75(1-2), p. 209-214, 2010.

https://doi.org/10.1016/i.petrol.2010.11.008

Amani, H. Study of enhanced oil recovery by rhamnolipids in a homogeneous 2D micromodel. Journal of Petroleum Science and Engineering, v. 128, p. 212-219, 2015.

https://doi.org/10.1016/i.petrol.2015.02.030

Anderson, W. Wettability Literature SurveyPart 2: Wettability Measurement. Journal of Petroleum Technology, v. 38(11), p. 1246-1262, 1986. https://doi.org/10.2118/13933-PA

Armstrong, R. T.; Wildenschild, D.; Bay, B. K. The effect of pore morphology on microbial enhanced oil recovery. Journal of Petroleum Science and Engineering, v. 130, p. 16-25, 2015.

https://doi.org/10.1016/j.petrol.2015.03.010

Babadagli, T. Analysis of oil recovery by spontaneous imbibition of surfactant solution. Oil and Gas Science and Technology, v. 60(4), p. 697710, 2005. https://doi.org/10.2516/ogst:2005049

Bryant, R. S.; Stepp, A. K.; Bertus, K. M.; Burchfield, T. E.; Dennis, M. et al. Microbial enhanced waterflooding field tests. SPE/DOE Improved Oil Recovery Symposium, 1994.

https://doi.org/10.2118/27751-MS

Câmara, J. M. D. A. et al. Application of rhamnolipid biosurfactant produced by Pseudomonas aeruginosa in microbial-enhanced oil recovery (MEOR). Journal of Petroleum Exploration and Production Technology, $25 \mathrm{fev}$. 2019. https://doi.org/10.1007/s13202-019-0633-x

Castro Dantas, T. N.; Moura, E. F.; Scatena Júnior, H.; Dantas Neto, A. A.; Gurgel, A. Micellization and adsorption thermodynamics of novel ionic surfactants at fluid interfaces. Colloids and Surfaces A: Physicochemical and Engineering Aspects, v. 207(1-3), p. 243-252, 2002.https://doi.org/10.1016/S0927-7757(02)00117-6
Cooper, D. G.; Goldenberg, B. G. Surface-Active Agents from Two Bacillus Species. Applied and Environmental Microbiology., v. 53(2), p. 224-229, 1987.

Costa, S. E. D.; Barros Neto, E. L.; Oliveira, M. C. A.; Santos, J. S. C. Mechanical and Petrophysical Analysis of Synthetic Sandstone for Enhanced Oil Recovery Applications. Brazilian Journal of Petroleum and Gas, v. 11(3), p. 131-140, 2017. https://doi.org/10.5419/bipg2017-0011

Craig Jr, F. F. The Reservoir Engineering Aspects Of Waterflooding. Henry L. Doherty Memorial Fund of AIME, 1993. 134p.

Curbelo, F. D. S.; Garnica, A. I. C.; Dantas, T. N. C.; Barros Neto, E. L. Oil Recovery by Ionic Surfactant and Sweep Efficiency Study in Sandstones. Brazilian Journal of Petroleum and Gas, v. 2(1), p. 9-16, 2008.

Curbelo, F. D. S.; Garnica, A. I. C.; Neto, E. L. B. Enhanced oil recovery and adsorption of ionic surfactant. Petroleum Science and Technology, v. 31(7), p. 663-671, 2013.

https://doi.org/10.1080/10916466.2010.523750

Deepika, K. V.; Kalam, S.; Sridhar, P. R.; Podile, A. R.; Bramhachari, P. V. Optimization of rhamnolipid biosurfactant production by mangrove sediment bacterium Pseudomonas aeruginosa KVD-HR42 using response surface methodology. Biocatalysis and Agricultural Biotechnology, v. 5, p. 38-47, 2016.

https://doi.org/10.1016/i.bcab.2015.11.006

Desai, J. D.; Banat, I. M. Microbial production of surfactants and their commercial potential. Microbiology and Molecular Biology Reviews, v. 61(1), p. 47-64, 1997.

Eastoe, J.; Dalton, J. Dynamic surface tension and adsorption mechanisms of surfactants at the air-water interface. Advances in Colloid and Interface Science, v. 85(2), p. 103-144, 2000. https://doi.org/10.1016/s0001-8686(99)00017-2

El-Sheshtawy, H. S.; Aiad, I.; Osman, M. E.; AboElnasr, A. A.; Kobisy, A. S. Production of biosurfactant from Bacillus licheniformis for microbial enhanced oil recovery and inhibition the growth of sulfate reducing bacteria. Egyptian Journal of Petroleum, v. 24(2), p. 155-162, 2015. https://doi.org/10.1016/i.ejpe.2015.05.005 
Fan, Y.; Gao, K.; Chen, J.; Li, W.; Zhang, Y. Lowcost PMMA-based microfluidics for the visualization of enhanced oil recovery. Oil and Gas Science and Technology, v. 73, 2018. https://doi.org/10.2516/ogst/2018026

Fernandes, P. L.; Rodrigues, E. M.; Paiva, F. R.; Ayupe, B. A. L.; Mclnerney, M. J.; Tótola, M. R. Biosurfactant, solvents and polymer production by Bacillus subtilis RI4914 and their application for enhanced oil recovery. Fuel, v. 180, p. 551-557, 2016. https://doi.org/10.1016/i.fuel.2016.04.080

Geetha, S. J.; Banat, I. M.; Joshi, S. J. Biosurfactants: Production and potential applications in microbial enhanced oil recovery (MEOR). Biocatalysis and Agricultural Biotechnology, v. 14, p. 23-32, 2018. https://doi.org/10.1016/i.bcab.2018.01.010

Gurkov, T. D.; Dimitrova, D. T.; Marinova, K. G.; Bilke-Crause, C. Gerber, C.; Ivanov, I. B. Ionic surfactants on fluid interfaces: Determination of the adsorption; Role of the salt and the type of the hydrophobic phase. Colloids and Surfaces A: Physicochemical and Engineering Aspects, v. 261(1-3), p. 29-38, 2005.

https://doi.org/10.1016/i.colsurfa.2004.11.040

Hassan, M.; Essam, T.; Yassin, A. S.; Salama, A. Optimization of rhamnolipid production by biodegrading bacterial isolates using PlackettBurman design. International Journal of Biological Macromolecules, v. 82, p. 573-579, 2016. https://doi.org/10.1016/i.ijbiomac.2015.09.057

Healy, M. G.; Devine, C. M.; Murphy, R. Microbial production of biosurfactants. Resources, Conservation and Recycling, v. 18(1-4), p. 41-57, 1996. https://doi.org/10.1016/S0921-3449(96)01167-6

Jönsson, B.; Kronberg, B.; Lindman, B. Surfactants and polymers in aqueous solution. Second ed. England: John Willey \& Sons, 2003.

Joshi, S.; Bharucha, C.; Jha, S.; Yadav, S.; Nerurkar, A.; Desai, A. J. Biosurfactant production using molasses and whey under thermophilic conditions. Bioresource Technology, v. 99(1), p. 195-199, 2008.

https://doi.org/10.1016/j.biortech.2006.12.010
Khajepour, H.; Mahmoodi, M.; Biria, D; Ayatollahi, S. Investigation of wettability alteration through relative permeability measurement during MEOR process: A micromodel study. Journal of Petroleum Science and Engineering, v. 120, p. 1017, 2014. https://doi.org/10.1016/j.petrol.2014.05.022

Kumar, A.; Mandal, A. Synthesis and physiochemical characterization of zwitterionic surfactant for application in enhanced oil recovery. Journal of Molecular Liquids, v. 243, p. 61-71, 2017. https://doi.org/10.1016/i.molliq.2017.08.032

Li, Y.; He, X.; Cao, X; Zhao, G.; Tian, X.; Cui, X. Molecular behavior and synergistic effects between sodium dodecylbenzene sulfonate and Triton X-100 at oil/water interface. Journal of Colloid and Interface Science, v. 307(1), p. 215220, 2007. https://doi.org/10.1016/j.jcis.2006.11.026

Liu, F.; Darjani, S.; Akhmetkhanova, N.; Maldarelli, C.; Banerjee, S.; Pauchard, V. Mixture Effect on the Dilatation Rheology of AsphaltenesLaden Interfaces. Langmuir, v. 33(8), p. 1927-1942, 2017.

https://doi.org/10.1021/acs.langmuir.6b03958

Makkar, R. S.; Cameotra, S. S.; Banat, I. M. Advances in utilization of renewable substrates for biosurfactant production. AMB Express, v. 1(1), p. 1-19, 2011. https://doi.org/10.1186/2191-0855-1-5

Malik, I. A.; Al-Mubaiyedh, U. A.; Sultan, A. S.; Kamal, M. S.; Hussein, I. A. Rheological and thermal properties of novel surfactant-polymer systems for EOR applications. Canadian Journal of Chemical Engineering, v. 94(9), p. 1693-1699, 2016. https://doi.org/10.1002/cjce.22541

McInerney, M.; Nagle, D.; Knapp, R. Microbially Enhanced Oil Recovery: Past, Present, and Future, p 215-238, 2005. In: Ollivier, B.; Magot, M. (ed) Petroleum Microbiology. ASM Press, Washington, DC. https://doi.org/10.1128/9781555817589.ch11

Miguez, M.; Nunes, P.; Azeredo, N.; Pedraza, S. F.; Vasconcelos, M.; Viana, O.; Coelho, M. A.; Amaral, P. Selection of yeasts for the production of L-phenyl acetyl carbinol by biotransformation in shake flasks. Chemical Engineering Transactions, v. 27, p. 163-168, 2012. 
Mozaffari, S.; Tchoukov, P.; Atias, J.; Czarnecki, J.; Nazemifard, N. Effect of Asphaltene Aggregation on Rheological Properties of Diluted Athabasca Bitumen. Energy and Fuels, v. 29(9), p. 5595-5599, 2015.https://doi.org/10.1021/acs.energyfuels.5b00918

Mulligan, C. N. Environmental applications for biosurfactants. Environmental Pollution, v. 133(2), p. 183-198, 2005.

https://doi.org/10.1016/i.envpol.2004.06.009

Pereira, J. F. B.; Gudiña, E. J.; Costa, R.; Vitorino, R.; Teixeira, J. A.; Coutinho, J. A. P.; Rodrigues, L. R. Optimization and characterization of biosurfactant production by Bacillus subtilis isolates towards microbial enhanced oil recovery applications. Fuel, v. 111, p. 259-268, 2013.

https://doi.org/10.1016/j.fuel.2013.04.040

Pornsunthorntawee, O.; Arttaweeporn, N.; Paisanjit, S.; Somboonthanate, P.; Abe, M.; Rujiravanit, R.; Chavadej, S. Isolation and comparison of biosurfactants produced by Bacillus subtilis PT2 and Pseudomonas aeruginosa SP4 for microbial surfactant-enhanced oil recovery. Biochemical Engineering Journal, v. 42(2), p. 172179, 2008.https://doi.org/10.1016/j.bej.2008.06.016

Rudyk, S.; Spirov, P.; Samuel, P.; Joshi, S. J. Vaporization of Crude Oil by Supercritical CO2at Different Temperatures and Pressures: Example from Gorm Field in the Danish North Sea. Energy and Fuels, v. 31(6), p. 6274-6283, 2017. https://doi.org/10.1021/acs.energyfuels.7b00313

Safdel, M.; Anbaz, M. A.; Daryasafar, A.; Jamialahmadi, M. Microbial enhanced oil recovery, a critical review on worldwide implemented field trials in different countries. Renewable and Sustainable Energy Reviews, v. 74, p. 159-172, 2017. https://doi.org/10.1016/j.rser.2017.02.045

Santos, F. K. G.; Barros Neto, E. L.; Moura, M. C. P. A.; Castro Dantas, T. N.; Dantas Neto, A. A. Molecular behavior of ionic and nonionic surfactants in saline medium. Colloids and Surfaces A: Physicochemical and Engineering Aspects, v. 333(1-3), p. 156-162, 2009.

https://doi.org/10.1016/i.colsurfa.2008.09.040

Soleymanzadeh, A.; Yousefi, M.; Kord, S.; Mohammadzadeh, O. A review on methods of determining onset of asphaltene precipitation. Journal of Petroleum Exploration and Production Technology, p. 1-22, 2018.

https://doi.org/10.1007/s13202-018-0533-5
Song, B.; Springer, J. Determination of Interfacial Tension from the Profile of a Pedant Drop using Computer-Aided Image ProcessingTheoretical. Journal of Colloid and Interface Science, v. 184, p. 64-76, 1996.

https://doi.org/10.1006/jcis.1996.0597

Sousa, J. R.; Correia, J. A. C.; Melo, V. M. M.; Gonçalves, L. R. B.; Cruz, A. J. G. Cinética e caracterização de ramnolipídeos produzidos por Pseudomonas aeruginosa MSIC02 utilizando glicerol como fonte de carbono. Quimica Nova, v. 37(3), p. 431-441, 2014.

https://doi.org/10.5935/0100-4042.20140064

Thomas, J. E. (ORG. . Fundamentos da engenharia de petróleo. Rio de Janeiro: Editora Interciência, 2001.

Yeh, M. S.; Wei, Y. H.; Chang, J. S. Enhanced production of surfactin from Bacillus subtilis by addition of solid carriers. Biotechnology Progress, v. 21(4), p. 1329-1334, 2005.

https://doi.org/10.1021/bp050040c

Youssef, N.; Randall Simpson, D.; Mclnerney, M. J.; Duncan, K. E. In-situ lipopeptide biosurfactant production by Bacillus strains correlates with improved oil recovery in two oil wells approaching their economic limit of production. International Biodeterioration and Biodegradation, v. 81, p. 127-132, 2013.

https://doi.org/10.1016/i.ibiod.2012.05.010

Zahid, S.; Sajid, H. L. U. R. A Review on Microbial Enhanced Oil Recovery With Special Reference to Marginal/Uneconomical Reserves. Society of Petroleum Engineers, Oklahoma City, 31 March-3 April 2007. Production and Operations Symposium. https://doi.org/10.2118/107052-MS

Zendehboudi, S.; Ahmadi, M. A.; Rajabzadeh, A. R.; Mahinpey, N.; Chatzis, I. Experimental study on adsorption of a new surfactant onto carbonate reservoir samples-application to EOR. Canadian Journal of Chemical Engineering, v. 91(8), p. 14391449, 2013. https://doi.org/10.1002/cjce.21806

Zhao, F.; Zhou, J-D.; Ma, F.; Shi, R-J.; Han, S-Q.; Zhang, J.; Zhang, Y. Simultaneous inhibition of sulfate-reducing bacteria, removal of $\mathrm{H} 2 \mathrm{~S}$ and production of rhamnolipid by recombinant Pseudomonas stutzeri Rhl: Applications for microbial enhanced oil recovery. Bioresource Technology, v. 207, p. 24-30, 2016.

https://doi.org/10.1016/j.biortech.2016.01.126 